\title{
The Politics of Chinese Investment in Africa under Belt and Road Initiative (BRI) Project
}

\author{
Andika Raka Dianjaya \\ Magister Ilmu Hubungan Internasional, Universitas Muhammadiyah Yogyakarta - Indonesia \\ Email: raka.tjitroharsojo@gmail.com \\ Submitted: 24 Juni 2019 | Accepted: 28 December 2019
}

\begin{abstract}
BRI project that will be held by China to connect countries in Europe, Asia, Middle East and Africa through Maritime Silk Road and Land Silk Road. This project will accelerate economy between countries who joined with this project. Africa as the potential partner have abundant resources energy that China require to maintain their position as the largest industrial producer in the world. China offering investment total of $\$ 60$ billion to Africa and pledge to assist them to build infrastructure, technology, agriculture and any project that Africa need to develop their countries so they can compete in this globalization revolution industrial era. On this paper, we will analyse China position with their BRI project in Africa using Political Economy Approach by Weingast \& Wittman and why China willingly to give investment total of $\$ 60$ billion to Africa which is some Africa countries maybe can't pay back their loans. Is this will become risk investment for China itself in the future?
\end{abstract}

Keywords: BRI, Investment, China, Africa, Development, Assistance, Debt.

\begin{abstract}
Abstrak
Proyek BRI yang akan diadakan oleh China untuk menghubungkan negara-negara di Eropa, Asia, Timur Tengah dan Afrika melalui Maritime Silk Road dan Land Silk Road. Proyek ini akan mempercepat ekonomi antar negara yang bergabung dengan proyek ini. Afrika sebagai mitra potensial memiliki energi sumber daya melimpah yang dibutuhkan Cina untuk mempertahankan posisi mereka sebagai produsen industri terbesar di dunia. China menawarkan total investasi \$60 miliar ke Afrika dan berjanji untuk membantu mereka membangun infrastruktur, teknologi, pertanian, dan proyek apa pun yang diperlukan Afrika untuk mengembangkan negara mereka sehingga mereka dapat bersaing dalam era industri revolusi globalisasi ini. Pada makalah ini, kami akan menganalisis posisi Cina dengan proyek BRI mereka di Afrika menggunakan Pendekatan Ekonomi Politik oleh Weingast \& Wittman dan mengapa Cina bersedia memberikan total investasi \$60 miliar ke Afrika yang beberapa negara Afrika mungkin tidak dapat membayar kembali pinjaman mereka. Apakah hal ini akan menjadi investasi risiko bagi China sendiri di masa depan.
\end{abstract}

Kata kunci: BRI, Investasi, China, Afrika, Pembangunan, Banuan, Hutang.

\section{INTRODUCTION}

China's 'One Belt One Road Initiative (BRI) was a grand design to increase economy between countries in Europe, Asia, Middle East, Latin America and Africa. This concept introduced by President Xi Jinping during his visit to Kazakhstan in September 2013. This is the first time for Chinese Leadership mentioned the strategic Vision (Xinhua, 2015). Xi suggested that China and Central Asia cooperate to build a Silk Road 
Economic Belt, specifically, road and rail construction along a route that following the ancient trade route connecting China to Europe via Central Asia. One month later, October 2013 in Indonesia. Xi proposed a connection building that will connect China-ASEAN community and offered guidance on constructing a 21st Century "Maritime Silk Road" to promote maritime cooperation. This Maritime Silk Road would pass along the Indian Subcontinent, doubling back around the Bay of Bengal then across the Indian Ocean, grazing the east coast of Africa before heading straight up through the Suez Canal (Murphy, 2016). During this period as well, Xi proposed establishing the Asian Infrastructure Investment Bank (AIIB) to finance infrastructure construction and promote regional inter-connectivity and economic integration between the regions. In October 2014, twenty- one Asian countries willing to join the AIIB as founding members by signed the Memorandum of Understanding on Establishing AIIB. Beijing will become the host city for AIIB's Headquarters. Finally on January 2015, founding members rose into 25 when New Zealand, Maldives, Saudi Arabia and Tajikistan officially joined. And today when this paper is written, total of member are joined grown into 93 worldwide.

Wherever Chinese leader goes, the BRI diplomacy always follows. During Forum on China-Africa Cooperation (FOCAC) in Beijing, September 2018. China signed memorandums of understanding (MOU) with 37 African countries from total of 53 countries who attended FOCAC forum and the African Union (AU) on jointly developing BRI (China daily, 2018). China's strategy to obtain African countries trust by offering $\$ 60$ Billion. $\$ 20$ billion in new credit lines, $\$ 15$ billion in foreign aid as grants, interestfree loans or concessional loans, $\$ 10$ billion for special fund for development financing, and $\$ 5$ billion for a special fund for financing imports from Africa. The remaining $\$ 10$ billion will come from Chinese company. It means China put $\$ 50$ billion from their own money in the stake.

China also offering investment in human resource. This kind of offer significantly increase since the last FOCAC in 2015. China offering government-sponsored training opportunities for 1,000 Africans in China. China will host 50,000 workshop, awarding 50,000 government scholarships and sponsoring 2,000 students exchange. To encourage exchanges related to 
science, technology and entrepreneurship, FOCAC 2018 would also to launch China-Africa Centre. Vocational training programs and investment in human resource are important to bound China-Africa relations. As FOCAC 2018 Action Plan pledges for training in defines and military program, anti-corruption officers, law-enforcement personnel, peacekeeping and police units, agriculture development and local Chinese language teacher. Another projects that well-received by Africans are training programs to share technical knowledge and transfer expertise (Robertson, Winslow \& Lina, 2018).

With China's influence by using investment in Africa led them indirectly have power to drive Africa policy. This main issues become our main topic of analysis. China's ambition to become super power nation led them to use investment as their main attraction to have influence on another countries, especially for development countries in Africa.

\section{BRI PROJECTS IN AFRICA}

History of China investment in Africa started by former China's President Jiang Zemin who visited Africa in May 1996. He proposed five points for establishing cooperation between China-Africa. They are friendship, sovereign equality, non- intervention, mutually beneficial development and international cooperation (Alden, C. (2005). This concept of win-win policy attract African attention. To follow up Jiang Zemin's proposal, China established Forum on China-Africa Cooperation (FOCAC) in 2000 in Beijing. This sealed cooperation between China and Africa. Trough FOCAC, China start to invest more to Africa and this action led into process of Belt Road Initiative (BRI).

There are several places that become China's first attention for BRI projects. Djibouti, Egypt, Ethiopia, Tanzania, Zambia and Angola. China invest the highest money on Egypt's Suez Canal Corridor than any other countries. Chinese company also got a contract for constructing the new multi-purpose terminal at Alexandria Port (Egypt). The Port operated by the Hong Kong based company, Hutchison Ports. On August 2018, another Chinese company, China Harbour Engineering Company (CHEC) started new project to construct new terminal basin in Sokhna Port south of the Suez Canal northeast of Egypt. The China Railway Construction Corporation (CRCC) got several contracts to build railways in Africa.

In Djibouti, China built Doraleh port with the jointly financed by China Merchant Holding Int. (CMHI) and 
Djibouti Port. They also initiated The Djibouti Ports \& Free Zones Authority (DPFZA). From Djibouti, to connect with Ethiopia, the rich resource neighbour country. Railway from Addis Ababa, the capital of Ethiopia to Djibouti capital and Doraleh Ports were created.

This Railway expected to be have $750 \mathrm{Km}$ length. This project was founded by loan from EXIM Bank. Both of China Railway Group Ltd (CREC) and China Civil Engineering Construction Corporation (CCECC) become the one that got the contract to build this project. Finally in 2017, Ethiopia-Djibouti railway and Djibouti port start to operate. In Kenya, There are Kenyan standard gauge railway (SGR) which is connected Mombasa with Nairobi. This SGR costly around $\$ 3.6$ billion and become the highest expensive infrastructure project since Kenya independent. China Road and Bridge Corporation (CRBC) become the one who get the contract to run this project. The next plan, there will be railway lines via Nairobi linking with South Sudan, Uganda, Rwanda and Burundi. As President Uganda said on August 2018, BRI will reach Uganda by constructing SGR that will connect Uganda with Kenya's Mombasa (Xinhuanet, 2018). With this BRI Project, many countries in Africa who join in BRI project believe with the help from China, the economic acceleration of African community will be flourished.

The Politics of investment become China method to gain influence in Africa. In political economy, investment only happens when actor believe they will get the return. Weingast \& Wittman (2006) use legislators as the sample. Expertise from legislators likened to investment, Good Expertise will need costly investment. Legislators will undertake this costly investment only if the system somehow compensates them from this (Weingast \& Wittman, 2006, p. 11). This perspective becomes a reference when state or actor doing investment.

\section{POLITICS, INVESTMENT AND CONTESTATION: LESSON FROM CHINESE INVESTMENT IN AFRICA}

China Political economy by using Foreign Direct investment as their method to gain influence in Africa become one big topics on this decade. This FDI's inclusive on Belt and Road Initiative project. Increasement on FDI in Africa each year. The latest data in 2017, China FDI seems to be escalated. This shown how China have interest to have cooperation with Africa (Caixin, 2018). 
Picture 1. China's Investment in Africa

China's direct investment in Africa

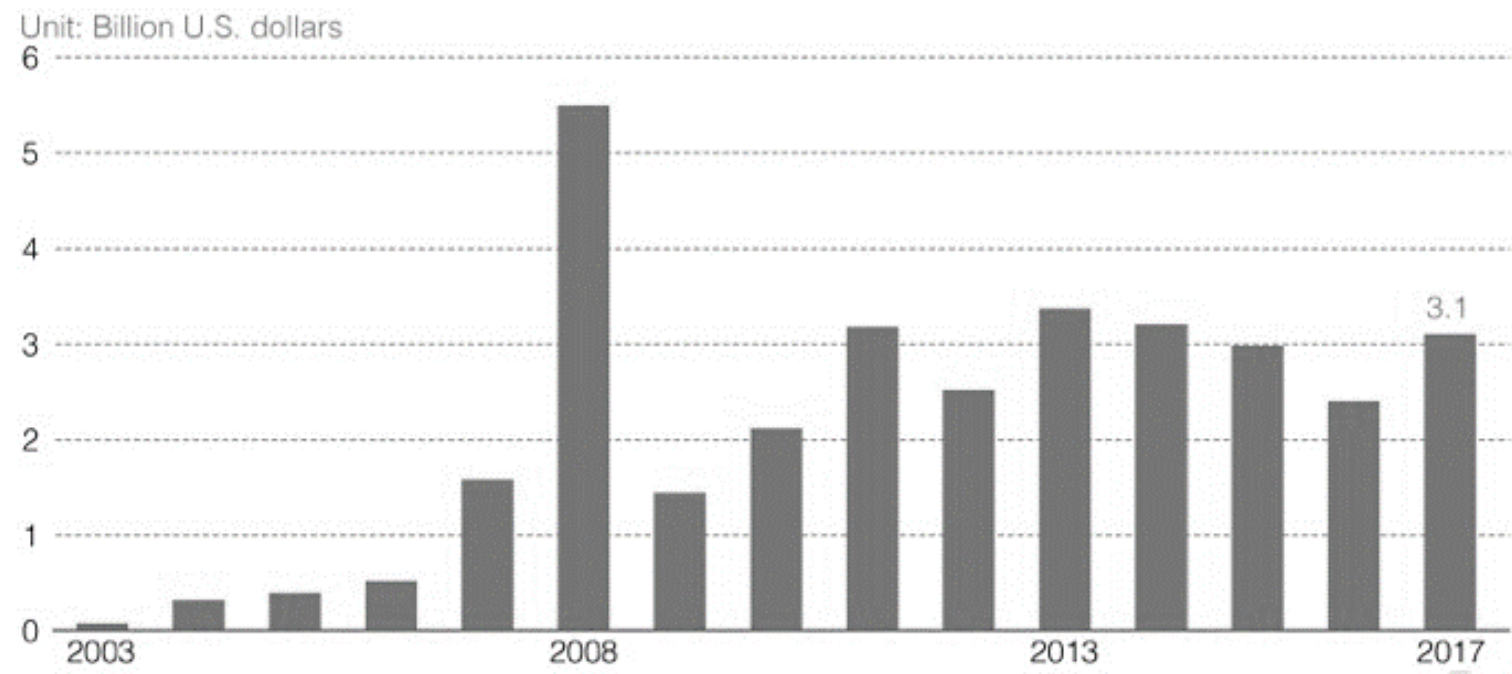

Source: China Ministry of Commerce

The ambition of China to build BRI in Africa lead into some speculation by questioning the true china intention. In a point of view political economy, China as an actor that have power to control wealth and policy to make accumulate their capital. To spread its control, China often using diplomatic or Political way to generate wealth. As Weingast \& Wittman (2006) said on their book "The Reach of Political Economy, The Oxford Handbooks of Political Science. They view Political Economy as the methodology of economics applied to the analysis of political behaviour and institutions. Political behaviour and institutions are themselves a subject of study, politics also becomes the subject of political economy. All of this is tied together by a set of methodologies, typically associated with economics, but now part and parcel of political science itself. In the book "The Reach of Political Economy", Weingast \& Wittman (2006) discussed a set of approachment that can be considerable used to analysis Policy or Act of political Actor from point of view Political Economy.

There are four approaches that used by Weingast \& Wittman (2006). First, The important to do research on endogenous institutions. They believe, research agenda on institutions follows a natural progression. First step that should be done by determining how institutions can affect behavior. This step is necessary conditions to know how endogenous institutions choices to deliver their policy. This approach can be used by collecting data and evidence (quantitative and qualitative). 
This data will be analysis and generated some hypotheses.

The second technical approach that the most challenging but at the same time one of the most exciting areas of research political economy concerns about the revelation and aggregation of information. This research will answers many puzzles. The third approach, using evolutionary models of human and political behaviour. Both economics and evolutionary models of human behaviour employ the concepts of survival and equilibrium (Alchian, 1950). Political economy is now at the confluence of two related paradigms, utility maximization and evolutionary fitness. Both employ survival arguments in the context of competitive forces (Weingast \& Wittman. 2006). The fourth approach, considering the spread of political economy to new area of research. The influence of actor, whether it is state, institutional, corporate or individual. They will have a motivation reason to do expansion or contraction. The size and wealth nation clearly have significant impact when doing negotiation to promote their interest.

In the next step, we will try to analyze BRI's policy using the four approachment on above. We will analyze BRI policy towards African countries and to understanding China position in the future. Information about BRI progress can be obtained through press confirmation, official statement, journal, and electronics news.

\section{ANALYSIS BRI PROJECT IN AFRICA}

BRI project for AFRICA already has been finished for some countries, like Djibouti, Kenya, Egypt, and Ethiopia. The other project for countries like South Sudan, Uganda, Rwanda and Burundi will be started soon. How can China massively give investment in the form of debt for Africa? is they are not afraid if those country can't pay their debt?. China sees Africa as potential partner for it. To make African flourish with the acceleration of economic growth, China offering them total of $\$ 60$ Billion. \$15 Billion in form of grants, interest-free loans or concessional loans. We don't have any data about exact money that China distribute for this project except the one that they already told.

BRI became an umbrella initiative which covers a multitude of investment project designed to promote and distribute the flow of goods, investment and people. According to chinapower.csis.org. BRI project has four goals points; (1) Improving intergovernmental communication to better align highlevel government policies like 
economic development strategies and plans for regional cooperation; (2) Strengthening the coordination of infrastructure plans to better connect hard infrastructure networks like transportation systems and power grids; (3) Encouraging the development of soft infrastructure such as the signing of trade deals, aligning of regulatory standards, and improving financial integration; (4) Bolstering people-to-people connections by cultivating student, expert and cultural exchanges and tourism.

All of this goals focusing to build cooperation to accumulate wealth. This socialist systems well narrated and implement by China. China try to become "great modern socialist country". Through BRI, China want to build multilateral International relations and become the new super power regime.

How to view BRI project in Africa from Political Economy approach by using political economy approach by Weingast \& Wittman? We'll use four approachment which is already described on above. Firstly, we should understand what China itself is. China is the one of the world's fastestgrowing economy power, with annual growth rates consistently above 6 percent. According to World Bank, China's GDP grew from $\$ 150$ billion in 1978 into $\$ 12.24$ trillion by 2017 .
This is make China become the world's second largest economy by nominal GDP. Since 2014, China become the world's largest economy by purchasing power parity. China is also become the world's largest exporter and second largest importer of goods. In the military power, China is recognized as nuclear weapon state and has the world's largest standing army and second largest defense budget. China is a permanent member of the United Nations Security Council. China become global partner of ASEAN plus mechanism. Not only that, china is also leading member of numerous formal and informal multilateral organizations, including Shanghai Cooperation Organization (SCO), World Trade Organization (WTO), Asian-Pacific Economic Cooperation (APEC), BRICS, BCIM, FOCAC and G20.

According to Weingast \& Wittman (2006), Institutions can be studied at three different levels. First, the most basic and common level takes institutions as given and studies their effects. Second, the first method can be used as a form of comparative institutional analysis to study the implications of different forms of institutions. Third, the deepest level of institutional analysis is to take the institutions themselves as endogenous; and to explain how and why institutions are structured in particular 
ways, and why some types of institutions survive but not others. The third approach is both the newest and the least explored of the three approaches to institutions and is therefore likely to be a major frontier in the coming years. At this point, we will use the deepest level of institutional analysis to understanding China Role in BRI project in Africa. BRI as the one biggest dream that China want to achieve, with BRI China will attain economic stability without only pursuing high growth. This can be associated that $\mathrm{Xi}$ called by China Dream of Grand Rejuvenation. This is can be seen clearly if $\mathrm{Xi}$ who represent Chinese Communist Party reflect China policy as well. BRI project that $\mathrm{Xi}$ propose was incorporated into 13th Five-Year Plan (2016-20) and inserted into Party Constitution at 19th China Communist Party Congress in 2017. With this point of view, BRI project in Africa can be seen as important as other BRI projects.

Analysis above will answer the question, why China willing to invest $\$ 60$ million and they don't afraid if the countries who borrowed the money can't payback. With information why BRI become so important for China, answering question if China believed that they will be the one who will reap the benefit. With BRI project in Africa done, maritime silk road between ASIA, AFRICA and EUROPE will be connected. China as the biggest player for exporter will reap benefit by this infrastructure acceleration trough BRI project. Africa, one of the places that have abundant resources became potential partner for China. China need stable energy source and energy secure route to maintain their position as the biggest production on the world market leading. This Analysis strengthened by China position in Djibouti. During the construction of Doraleh Port, China built military base as well. The location only need 5 minute from Doraleh Port. This Base will be used by People's Liberation Army Navy (PLAN). From this new vantage point, the PLAN is able to overlook one of the most important maritime chokepoints in the world: the Gulf of Aden, specifically the Bab-elMandeb Strait (Wang, Monica, 2018). Djibouti become strategic location to over watch and control situation in Gulf Aden Area and area surrounding. This is one of China ways to provide security in BRI project and to secure their interest in Africa.

FOCAC, one of the platform forum that bring China and Africa into Sustainability Corporation. China sees Africa potential and through development corporation China success to win Africa sides. Development of infrastructure will help African economy growth and to attract investment in labour-intensive 
manufacturing that can generate employment in Africa. China Investment in Africa have double meaning if Africa not carefully handle this investment with careness. Africa's debt to China will rise into another problem. Debt should be managed properly and spent it on activities that will promote inclusive economic growth. The failure for paying debt will endanger social and economy debtor countries. This case already happen in Sri Lanka, cause Srilanka can't pay the debt. They handing over the Hambantota port to China company for 99 years. With this analysis, can be deduced if China already prepare long term thinking to make BRI project success for them. All those huge investment merely an action that will accumulate their profits.

As seen from approachment of political economy by Weingast \& Wittman (2006). Political economy is now at the confluence of two related paradigms: utility maximization and evolutionary fitness. Both employ survival arguments in the context of competitive forces. China is one of major economy force that trying to maintain their position and it's gradually moving to become Super Power nation who will replace U.S positions. China competitive can be seen today, China become the leading member of intergovernmental organizations. In Africa itself, China become dominant country who actively giving aid in humanitarian and development assistance. China hegemony as major power in Africa shifting Western domination in Africa. When western countries stuck in racism's issues, China bring equality as the same development countries to cooperate with Africa. This soft diplomacy gain trust in Africa and maintain China position as African people friend.

In term of development projects, China companies won many contract to build railways, ports, factory, and roads in Africa. This happen because how the Chinese companies competitiveness and survivalism to gain profit led them to win big contract. We can't forget as well how China position for African people. China has power to influence African countries to choose their Chinese company for handling the project as well. People can see how many Chinese companies working in BRI projects in Africa.

The last thing from Weingast \& Wittman (2006) political economy approachment. The influence of actor who will determine nation policy. China as an actor who leading BRI project can be seen as an important key to bring new economic paradigm. China have the power, both economic and military. The Grand project of China to able to realize BRI make 
other big countries should be aware. Even Though, there are fear from western countries about China investment for Africa countries, regarding debt trap China diplomacy (Dahir, 2019). In Africa point of view, this is become a chance for them to reach acceleration in economy and technology that will bring prosperity for their land.

\section{CONCLUSION}

BRI projects is one of China's biggest ambition that will connected China-Asia-Africa-Europe through Maritime route and Land route. This grand project coming from China supreme leader, Xi Jinping. This project incorporated into 13th Five year Plan (2016-2020) and inserted in China Communist Party Constitution in 2017. Africa as the one of incomparable region for China BRI project, this statement strengthened by total of $\$ 60$ billion China's investment for Africa. Using political economy approach by Weingast \& Wittman (2006), we can see how China view BRI project in Africa is important as another BRI project as well. China really see Africa as potential partner for their cooperation, and this will promote China position in Africa too. Developing Africa infrastructure and technology with loans systems formup Africa dependency to China. This dependency will drive Africa policy to be more leaning with China preferences. China need stabilization of energy and economy and Africa will provide that through this BRI project.

\section{REFERENCE}

Abdi, Dahir. L. (2019) The "Debt-Trap" Narrative Around Chinese Loans Shows Africa's Weak Economy Diplomacy (Online). Available at: https://qz.com/africa/1542644/chinadebt-trap-talk-shows-africas-weakeconomic-position/ (Accessed at 4 April 2019).

Alden, C. (2005) "China in Africa", Survival Global Politics and Strategy, 47(3), pp. 147-164 (Online). Availble at: doi:10.1080/00396330500248086 (Acce ssed: 29 March 2019).

Breuer, Julia. (2017) Two Belts, One Road? The role of Africa in China's Belt \& Road Initiative (Online). Available at: https://www.euchina.net/uploads/tx_news/Blickwechs el_OBOR-Afrika_Maerz2018_03.pdf. (Accessed: 30 March 2019).

Caixin. (2018) Chart of the Day: China's Investment in Africa (Online). Available at: https://www.caixinglobal.com/201809-04/chart-of-the-day-chinasinvestment-in-africa-101322391.html (Accessed: 29 March 2019).

Chinadaily. (2018) China signs MOUs with 37 African countries, $A U$ on $B \& \mathrm{R}$ Development (Online). Available at: https://eng.yidaiyilu.gov.cn/qwyw/rdx w/65620.htm. (Accessed at 29 March 2019).

Jonathan, Hilman, E. (2018) China's Belt and Road Is Full of Holes (Online). Available at: https://www.csis.org/analysis/chinasbelt-and-road-full-holes (Accessed at 29 March 2019). 
Lawson, T. (1989) "Realism and Instrumentalism in the Development of Econometrics." Oxford Economic Papers, 41(1), new series, 236-258 (Online). Available at: http://www.jstor.org/stable/2663191 (Accessed at 29 March 2019).

Murphy, D. (2016) “One Belt One Road: International Development Finance With Chinese Characteristics." In Davies G., Goldkorn J., \& Tomba L. (Eds.), Pollution (pp. 245-252). Australia: ANU Press (Online). Available at: http://www.jstor.org/stable/j.ctt1rqc93 4.23 (Accessed: 29 March 2019).

Robertson, Winslow \& Benabdallah, Lina. (2018) Xi Jinping Pledged $\$ 60$ Billion for Africa. Where Will the Money Go? (Online). Available at: https://www.washingtonpost.com/new s/monkey-cage/wp/2018/09/17/xijinping-pledged-60-billion-for-africawhere-will-the-moneygo/?noredirect $=$ on\&utm_term $=$.fe0eac 1663f9 (Accessed: 29 March 2019).

Steve Shuklian. (1995) "Marx, Dewey, and the Instrumentalist Approach to Political Economy." Journal of Economic Issues, 29(3), 781-805 (Online). Available at:

http://www.jstor.org/stable/4226988 (Accessed: 29 March 2019).
Wang, Monica. (2018) China's Strategy in Djibouti: Mixing Commercial and Military Interests (Online). Available at: at:https://www.cfr.org/blog/chinasstrategy-djibouti-mixing-commercialand-military-interests (Accessed: 3 April 2019).

Weingast \& Wittman. (2006) The Reach Of Political Economy. The Oxford Handbooks of Political Science, pp. 325.

Xinhua. (2015) Chronology of China's Belt and Road Initiative (Online). Available at: http://english.gov.cn/news/top_news/ 2015/04/20/content_28147509256632 6.htm. (Accessed: 29 March 2019).

Xinhua. (2015) Full Text: China's second Africa policy paper (Online). Available at: http://www.china.org.cn/world/201512/05/content_37241677.htm. (Accessed: 30 March 2019).

Xinhuanet, (2018) Interview: Ugandan President Says BRI Critical to Africa's Fast-Track Development (Online). Available at: at:http://www.xinhuanet.com/english/ 2018-08/31/c_137431660.htm (Accessed: 30 March 2019). 